\title{
Molecular Cloning of the Complementary DNA and Gene That Encode Mouse Brain Natriuretic Peptide and Generation of Transgenic Mice That Overexpress the Brain Natriuretic Peptide Gene
}

\author{
Yoshihiro Ogawa, Hiroshi Itoh, Naohisa Tamura, Shin-ichi Suga, Takaaki Yoshimasa, Masahiro Uehira, * \\ Saburo Matsuda, * Shozo Shiono, * Hirofumi Nishimoto, * and Kazuwa Nakao \\ Second Division, Department of Medicine, Kyoto University School of Medicine, Kyoto 606, Japan; \\ and * Shionogi Research Laboratories, Shionogi \& Co., Ltd., Osaka 553, Japan
}

\begin{abstract}
Brain natriuretic peptide (BNP) is a cardiac hormone that occurs predominantly in the ventricle. To study the roles of BNP in chronic cardiovascular regulation, we isolated mouse BNP cDNA and genomic clones, and generated transgenic mice with elevated plasma BNP concentration. The mouse BNP gene was organized into three exons and two introns. Two BNP mRNA species were identified, which were generated by the alternative mRNA splicing. The ventricle was a major site of BNP production in mice. Mouse preproBNP was a 121- (or 120-) residue peptide, and its $\mathrm{COOH}$-terminal 45-residue peptide was the major storage form in the heart. Transgenic mice carrying the human serum amyloid $P$ component/mouse BNP fusion gene were generated so that the hormone expression is targeted to the liver. In the liver of these mice, considerable levels of BNP mRNA and peptide were detected, reaching up to 10-fold greater than in the ventricle. These animals showed 10- to 100fold increase in plasma BNP concentration accompanied by elevated plasma cyclic GMP concentration, and had significantly lower blood pressure than their nontransgenic littermates. The present study demonstrates that these mice provide a useful model system with which to assess the roles of BNP in cardiovascular regulation and suggests the potential usefulness of BNP as a long-term therapeutic agent. (J. Clin. Invest. 1994. 93:1911-1921.) Key words: atrial natriuretic peptide • blood pressure - cardiovascular regulation - cyclic guanosine monophosphate • serum amyloid $P$ component
\end{abstract}

\section{Introduction}

Cardiovascular function and homeostasis are maintained through complex interactions among multiple regulatory fac-

The nucleotide sequence reported in this paper has been submitted to the GenBank Data Bank with accession number D16497.

Address correspondence to Dr. Kazuwa Nakao, Second Division, Department of Medicine, Kyoto University School of Medicine, 54 Shogoin Kawahara-cho, Sakyo-ku, Kyoto 606, Japan.

Received for publication 3 August 1993 and in revised form 4 January 1994.

J. Clin. Invest.

(c) The American Society for Clinical Investigation, Inc.

$0021-9738 / 94 / 05 / 1911 / 11 \$ 2.00$

Volume 93, May 1994, 1911-1921 tors. One of these factors, atrial natriuretic peptide (ANP), ${ }^{1}$ is synthesized in and secreted from the heart, and acts as a cardiac hormone with a variety of biological actions including natriuresis, diuresis, vasorelaxation, and inhibition of renin and aldosterone secretion $(1,2)$. ANP is found at the highest concentration in the atrium, and the circulating ANP is mainly derived from the atrium (1-3). Although the ANP gene expression in the ventricle is $\sim 100$-fold lower than in the atrium, ventricular expression is up-regulated in patients with congestive heart failure (CHF) and animal models of ventricular hypertrophy (4-6).

Brain natriuretic peptide (BNP), originally isolated from the porcine brain (7), shows a sequence homology to ANP and has central and peripheral actions similar to those of ANP. We previously showed that BNP is found at the highest concentration in the heart rather than in the brain and that BNP also acts as a cardiac hormone $(8,9)$. Furthermore, we demonstrated that BNP occurs predominantly in the ventricle (9-11), which sharply contrasts to ANP, a cardiac hormone primarily from the atrium. The BNP gene expression is also increased in diseased ventricles (10-12). The plasma BNP concentration is markedly elevated in patients with $\mathrm{CHF}$ in proportion to its severity (up to $500 \mathrm{fmol} / \mathrm{ml}$ ), and exceeds the plasma ANP concentration in severe cases (10). Noteworthy is the augmented secretion of BNP in the early phase of acute myocardial infarction, when the plasma ANP concentration is unchanged (13). These findings suggest that BNP plays important roles in cardiovascular regulation. Indeed, we demonstrated that acute administration of BNP (14) as well as ANP (15) improves left ventricular function in patients with $\mathrm{CHF}$ by its prominent natriuretic and vasodilatory activity. Previous studies, however, gave no definite evidence for the physiologic and pathophysiologic roles of BNP in chronic cardiovascular regulation.

Transgenic mice provide a unique experimental paradigm for studying the complex phenotypic effects of an altered gene in a living animal. This approach has greatly enhanced our understanding in cardiovascular research field (16). To understand the roles of BNP in long-term cardiovascular regulation, we tried to generate transgenic mice with chronically elevated plasma BNP concentration. The major circulating forms of

1. Abbreviations used in this paper: ANP, atrial natriuretic peptide; BNP, brain natriuretic peptide; BP, blood pressure; CNP, C-type natriuretic peptide; $\mathrm{CHF}$, congestive heart failure; GC, guanylyl cyclase; HP-GPC, high-performance gel-permeation chromatography; -LI, -like immunoreactivity; SAP, serum amyloid P component; SBP, systolic BP. 
BNP are 26-, 45-, and 32-amino acid peptides in pigs, rats, and humans (8-10), respectively. Thus, the structure of BNP varies considerably among species. Accordingly, rat BNP is almost equipotent to rat ANP in natriuresis and diuresis, while human BNP has no significant activity in rats (17), suggesting the presence of a unique species specificity of the biological actions of BNP. To assess the biological actions of BNP in mice, therefore, it is necessary to elucidate the structure of mouse BNP.

In this context, in the present study, we first isolated mouse BNP cDNA and genomic clones. By using the mouse BNP coding sequences, we succeeded in the generation of transgenic mice with elevated plasma BNP concentration.

\section{Methods}

Isolation of mouse BNP $c D N A$ and genomic clones. A BALB/c mouse heart cDNA library in $\lambda \mathrm{gt} 10$ vector (Clontech Inc., Mountain View, CA) was screened with the ${ }^{32} \mathrm{P}$-labeled rat BNP cDNA probe (11). Prehybridization and hybridization were carried out as described (18, 19). The filters were washed in $2 \times \operatorname{SSC}(1 \times \operatorname{SSC}$ is $0.016 \mathrm{M} \mathrm{NaCl}$, $0.016 \mathrm{M} \mathrm{Na}$ citrate) and $0.1 \%$ SDS three times at $60^{\circ} \mathrm{C}$. Five positive clones were obtained from $5 \times 10^{5}$ plaques, all of which contained the full-length mouse BNP cDNA. To isolate the mouse BNP genomic clone, a mouse genomic DNA library in $\lambda$ EMBL3 SP6/T7 (Clontech Inc.) was screened as described $(18,19)$ with the obtained mouse BNP cDNA fragment. Approximately $1 \times 10^{6}$ clones were screened and nine positive signals were obtained. DNA from one clone ( $\lambda$ MBNP20) harbored an about 11-kb mouse BNP genomic fragment, and a 3.5-kb EcoRI fragment of this clone was subcloned into pBluescript vector (Stratagene, Inc., La Jolla, CA) (pBSMBNPGEN) for further analysis (Fig. 1 $A$ ).

Primer extension analysis. A synthetic oligonucleotide (5'TCTGGGACAGCACCTTCAGGAGATCCATGC-3') corresponding to +77 to +106 of the mouse BNP gene (Fig. $1 B$ ) was end-labeled with [ $\gamma-{ }^{32} \mathrm{P}$ ]ATP, and hybridized to $50 \mu \mathrm{g}$ of total RNA extracted from the mouse heart and liver for $4 \mathrm{~h}$ at $42^{\circ} \mathrm{C}$. Primer extension analysis was carried out as previously described (19).

Construction of human serum amyloid P component (SAP)/mouse $B N P$ fusion gene. A fusion gene comprising the human SAP promoter (20) and mouse BNP coding sequences was designed so that the hormone expression is targeted to the liver (Fig. 2). The 1.2-kb SacI-PstI fragment of the mouse BNP gene was subcloned into pBluescript vector (pBSMBNP). To maximize the transgene expression, the AT-rich sequences in the 3 -untranslated region of the mouse BNP gene were not included in the fusion gene. The pSG 2 vector, a modified form of pLG 1 vector (21), in which the $H-2 L^{d}$ promoter was replaced by the 600-bp HindIII-AvrII human SAP promoter (20) and an SalI linker was introduced at the XhoI site (a generous gift from Dr. J. Miyazaki, Tokyo University), was digested with BamHI and EcoRI. This human SAP promoter was capable of directing the developmental and liverspecific expression of heterologous genes in transgenic mice (20). The PvulI-EcoRV fragment of pBSMBNP was ligated to blunt-ended BamHI and EcoRI sites of the pSG 2 vector, which resulted in the human SAP/mouse BNP fusion gene, followed by the 3'-untranslated region of rabbit $\beta$-globin gene in pSG 2 (Fig. 2). All predicted junction sequences were verified by DNA sequencing.

Generation and identification of transgenic mice. The HindIII-SalI fragment of the human SAP/mouse BNP fusion gene (Fig. 2) was purified and microinjected into the pronucleus of fertilized C57BL/6J (Nippon Clea, Osaka, Japan) eggs using standard techniques (22). Mice carrying the transgene were identified by Southern blot analysis of DNA extracted from tail tissues using the ${ }^{32} \mathrm{P}$-labeled 0.86-kb EcoRIPstI mouse BNP gene fragment (Fig. $1 A$ ). To determine the number of transgene copies, 20 copies of the microinjected DNA were immobilized on nylon filters and hybridized with the same probe.
DNA sequencing. All DNA sequences were determined using the dideoxy chain-termination method (23) by subcloning into pBluescript vector and were confirmed by reading both DNA strands.

Peptides. Mouse BNP[108-121], mouse BNP[77-121], [ $\left.\mathrm{Tyr}^{92}\right]-$ mouse BNP[93-121], rat BNP, porcine BNP-32, human BNP, and C-type natriuretic peptide (CNP) were synthesized by the solid phase method. Alpha-human ANP and $\alpha$-rat ANP were purchased from Peptide Institute, Inc., Minoh, Japan.

Preparation of mouse polyclonal antibody. Mouse BNP[108-121] ( $4 \mathrm{mg}$ ) was conjugated to bovine thyroglobulin ( $18.5 \mathrm{mg}$, Sigma Chemical Co., St. Louis, MO) using carbodiimide coupling procedure (3, 10). $10 \mathrm{BALB} / \mathrm{c}$ mice were immunized with subcutaneous injection of the conjugate containing $20 \mu \mathrm{g}$ of the peptide emulsified in complete Freund's adjuvant ( Difco Laboratories, Detroit, MI) over a period of 2 mo at 2-3-wk intervals. Sera were periodically screened for the antibody titer by the RIA with ${ }^{125} \mathrm{I}-\left[\mathrm{Tyr}^{92}\right]$-mouse BNP[93-121] as described below.

Development of RIA for mouse BNP. [ $\mathrm{Tyr}^{92}$ ]-mouse BNP[93-121] $(1 \mu \mathrm{g})$ was radioiodinated by the chloramine-T method as previously described $(3,10)$. The specific activity of ${ }^{125} \mathrm{I}-\left[\mathrm{Tyr}^{92}\right]$-mouse BNP [93121] ranged from 500 to $900 \mu \mathrm{Ci} / \mu \mathrm{g}$. RIA for mouse BNP was performed following the method of RIA for ANP (3). The antiserum (M-7) could be used at a final 1:10,000 dilution.

Plasma samplings and tissue preparations. Blood was sampled from the retro-orbital sinus of mice, immediately transferred to chilled microtubes containing $\mathrm{Na}_{2}$ EDTA $(1 \mathrm{mg} / \mathrm{ml})$ and aprotinin $(1,000$ $\mathrm{KIU} / \mathrm{ml}$ Ohkura Pharmaceutical, Kyoto, Japan) and centrifuged at $4^{\circ} \mathrm{C}$. Hearts, livers, and other tissues were obtained as described $(9$, 11). The apical half of the ventricle of the heart was used as the ventricular sample to prevent atrial contamination. Tissue and plasma samples were frozen in liquid nitrogen, and stored at $-70^{\circ} \mathrm{C}$ until use.

Northern blot analysis. Total RNA was extracted in $4 \mathrm{M}$ guanidium thiocyanate buffer as described $(4,10)$. Northern blot analysis was performed using the ${ }^{32} \mathrm{P}$-labeled rat ANP cDNA (4) and full-length mouse BNP cDNA fragments as probes.

Peptide and cyclic GMP (cGMP) measurements. Peptide extraction was carried out as described $(9,11)$. The ANP-like immunoreactivity (-LI) and BNP-LI concentrations in tissues and plasma were determined by the RIAs for ANP (3) and mouse BNP, respectively. The cross-reactivities of mouse BNP [77-121] in the RIA for ANP were $<0.01 \%$. Plasma cGMP concentrations were determined as described (24).

High-performance gel permeation chromatography (HP-GPC). HP-GPC was performed on a TSK-GEL G2000 SW column (7.5 $\times 600 \mathrm{~mm}$, Toyo Soda, Tokyo, Japan), eluted with $10 \mathrm{mM}$ trifluoroacetic acid containing $0.3 \mathrm{M} \mathrm{NaCl}$ and $30 \%$ acetonitrile as a solvent as described $(3,10)$. The flow rate was $0.3 \mathrm{ml} / \mathrm{min}$ and the fraction volume was $0.36 \mathrm{ml}$.

Blood pressure (BP) measurements. Systolic BP (SBP) was measured by the tail cuff method (PS-200, Riken-Kaihatsu, Tokyo, Japan) (25). At least 10 readings were taken for each measurement. Direct BP measurements were also performed $6 \mathrm{~h}$ after implantation of carotid artery catheter in unrestrained, conscious animals. Continuous recordings were monitored by a polygraph system (RM-6000, Nihon Kohden, Tokyo, Japan) via a pressure transducer (P10 EZ-1, Nihon Kohden). The SBP levels measured by the tail cuff method correlated well with those by the direct measurement $(r=0.962 P<0.01)$ (not shown).

\section{Results}

Isolation and characterization of mouse BNP CDNA and genomic clones. Fig. 1 shows the schematic representation of the restriction endonuclease map and structure of the mouse BNP gene $(A)$ and its 1,410-bp nucleotide and deduced amino acid sequences $(B)$. The deduced amino acid sequence of the cod- 
(A)

(B)

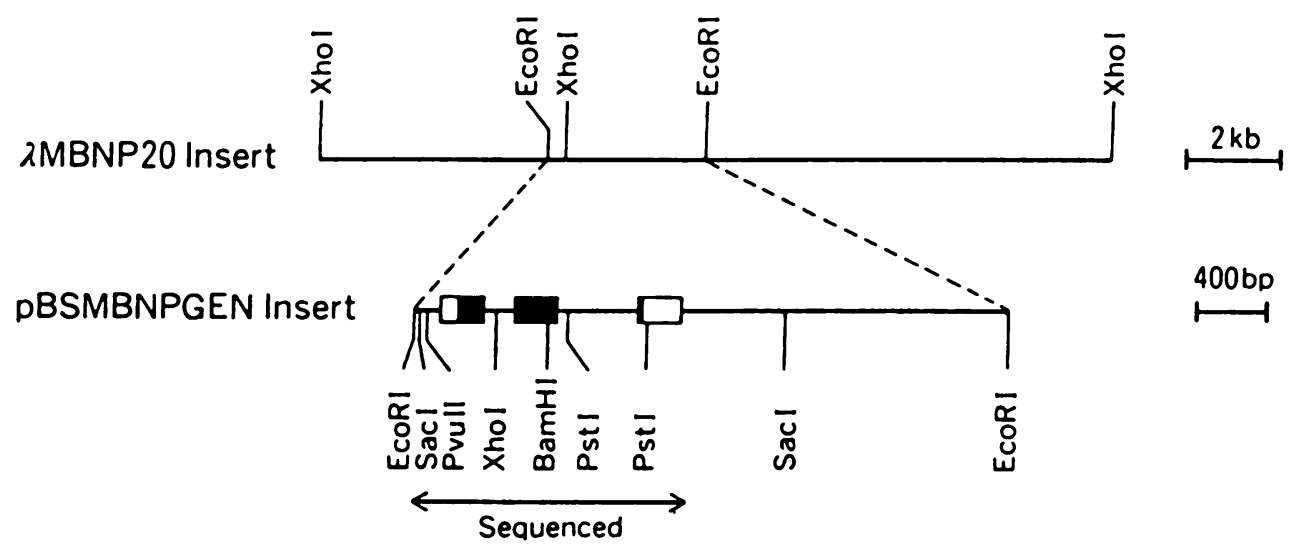

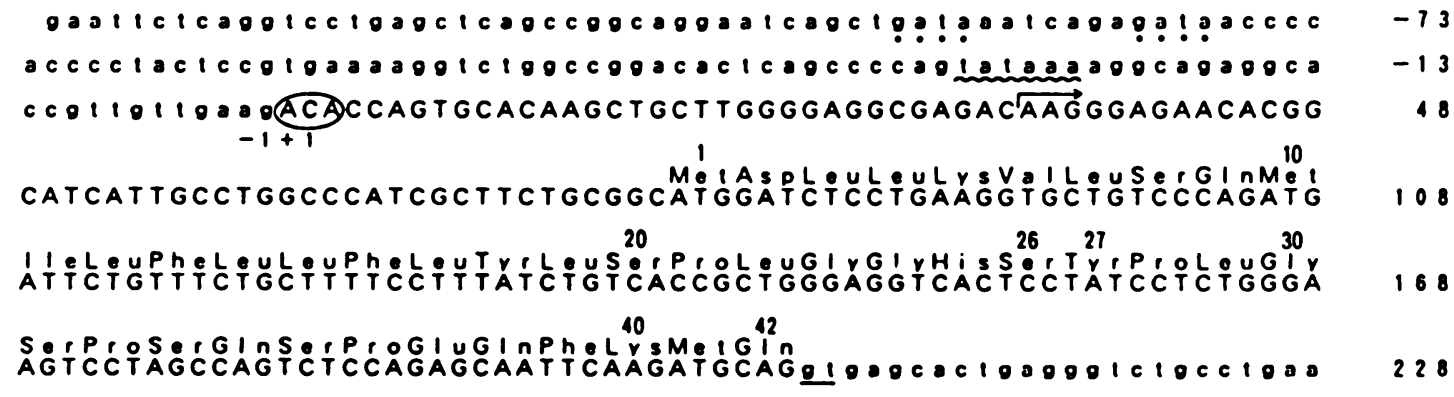

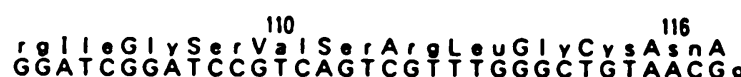

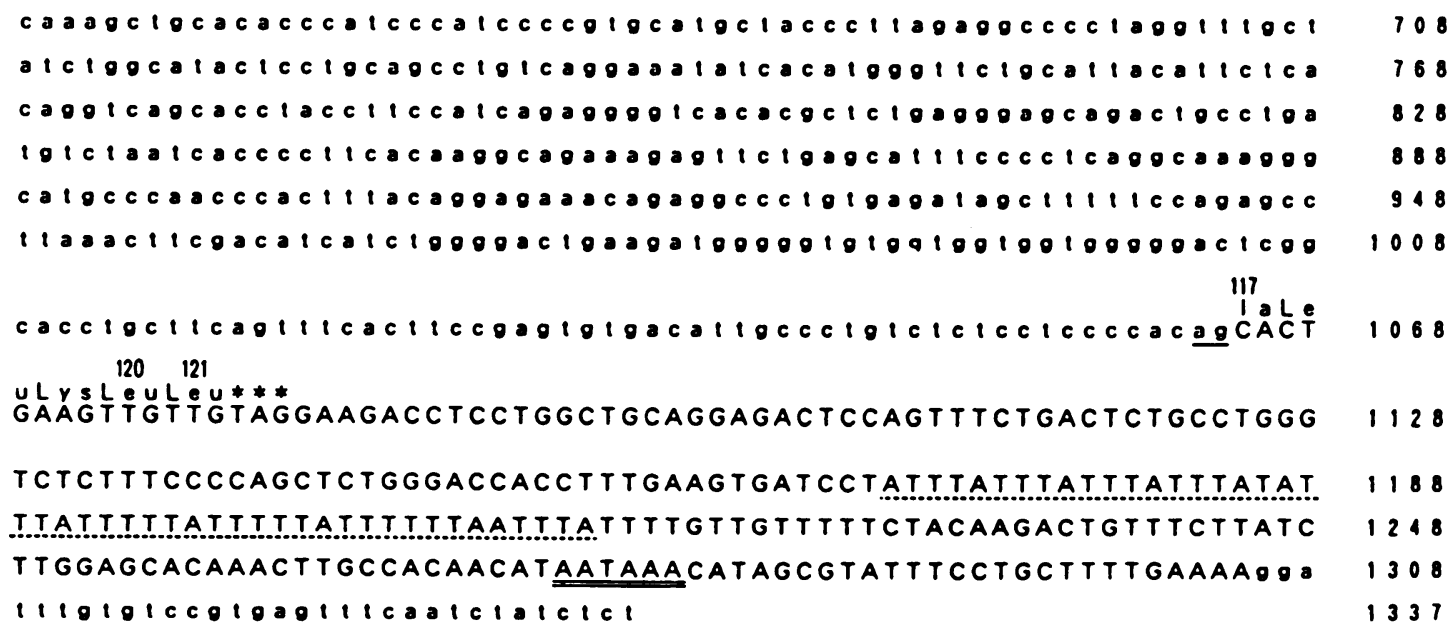

Figure 1. $(A)$ Schematic representation of the restriction endonuclease map and structure of the mouse BNP genomic clone ( $\lambda$ MBNP20) and its 3.5-kb EcoRI fragment (pBSMBNPGEN). Exons are boxed and coding regions are indicated by closed boxes. ( $B)$ Nucleotide and deduced amino acid sequences of the mouse BNP gene. Flanking and intron sequences are represented by lower-case letters, and exon sequences by upper-case letters. Splicing donor and acceptor consensus sequences are underlined. Symbols indicate two GATA sequences (. . . .), the transcription start site (circled), a TATA box ( wavy line), the stop codon $\left({ }^{* * *}\right)$, the AT-rich sequences (dotted line), and the polyadenylation signal (doubly underlined). The 5'-end of $\lambda \mathrm{MBNPcDNA5}$ is depicted by an arrow. The Lys ${ }^{43}$ residue, removed in $\lambda \mathrm{MBNPcDNA4}$, is boxed. The nucleotide sequence is numbered, with +1 referring to the major transcription start site. 


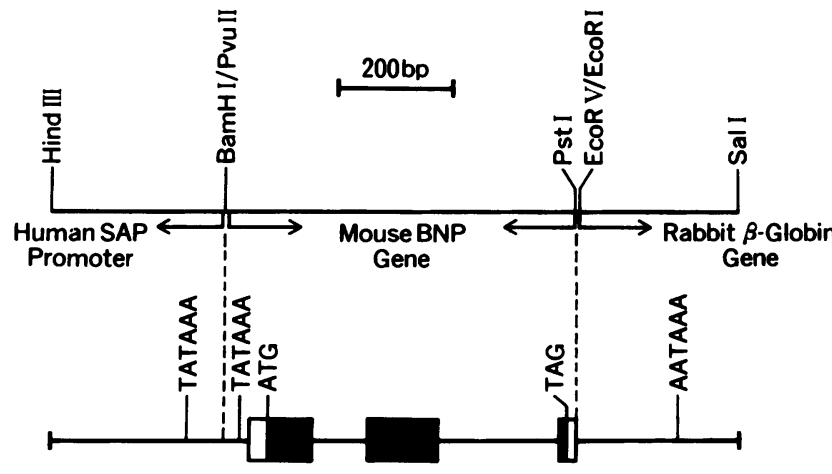

Figure 2. Schematic representation of the human SAP/mouse BNP fusion gene. Exons are boxed and coding regions are denoted by closed boxes.

ing region was identical to that of a mouse BNPcDNA clone ( $\lambda$ MBNPcDNA5) with an open reading frame for 121 amino acids. Comparison of the genomic and CDNA sequences revealed that the mouse BNP gene was organized into three exons and two introns. Splicing donor and acceptor consensus sequences (26) were located at the putative exon/intron borders. A variant cDNA clone ( $\lambda$ MBNPcDNA4) was found, which contained a three-nucleotide (AAG for Lys ${ }^{43}$ ) shorter coding sequence with no frame shift (Fig. $1 B$ ). The $\lambda \mathrm{MBNPcDNA} 5 / \lambda \mathrm{MBNPcDNA} 4$ ratio was $3: 2$ in $5 \mathrm{cDNA}$ clones isolated. The amino acid sequence is numbered based on that deduced from the $\lambda$ MBNPcDNA5 clone. A potential initiation methionine codon (ATG) occurred at nucleotide position $+79 \sim+81$, representing a reasonable translation start site. A TATA box occurred at nucleotide position $-29 \sim-24$. In the 5'-flanking region, there were two GATA elements (27) $60 \mathrm{bp}$ and $49 \mathrm{bp}$ upstream to the TATA box. In the 3 '-un-translated region, there were a typical polyadenylation signal
(AATAAA) 23 bp upstream to the poly (A) tail and the ATrich sequences implicated in mRNA instability (28).

Analysis of the deduced amino acid sequence revealed that mouse preproBNP comprises 121 (or 120 without Lys $^{43}$ ) amino acids (Fig. 3 ). Mouse preproBNP had a 78\%, $45 \%$, and $43 \%$ homology to rat, porcine, and human preproBNPs (2932 ), respectively. The $\mathrm{NH}_{2}$-terminal 26 amino acids represented the signal peptide. The proteolytic processing site that generates rat BNP was also found in mouse preproBNP ( $\mathrm{Arg}^{73}$ $\left.\mathrm{Val}^{74}-\mathrm{Leu}^{75}-\mathrm{Arg}^{76}\right)$. This proteolytic cleavage results in the COOH-terminal 45-residue peptide (mouse BNP [77-121]). Mouse BNP [77-121] was only $64 \%$ homologous to rat BNP (29). In the $\mathrm{COOH}$ terminus, two cysteine residues ( $\mathrm{Cys}^{99}$ and Cys ${ }^{115}$ ) occurred to form a 17-residue ring structure (Fig. 3).

Mapping of transcription start site of mouse BNP gene. To determine the transcription start site, primer extension was performed (Fig. 4). Using total RNA from the heart, three positive bands were obtained, which were located 29 bp downstream to the TATA box. No positive signals were detected with RNA from the liver and yeast tRNA. The most upstream nucleotide among the positive signals was assigned as the major transcription start site (referring as +1 in Fig. $1 B$ ). The 5 '-end of the longest cDNA clone isolated in the present study ( $\lambda$ MBNPcDNA5) was located 35 bp downstream to the major transcription start site (Fig. $1 B$ ).

$B N P$ gene expression in mice. Northern blot analysis identified a single mouse BNP mRNA species of $0.9 \mathrm{~kb}$ in size in the atrium as well as in the ventricle of 10 -wk-old $\mathrm{BALB} / \mathrm{c}$ mice (Fig. 5). The BNP mRNA level in the ventricle was almost the same as that in the atrium. By contrast, although a high level of ANP mRNA was present in the atrium, no appreciable amount of ANP mRNA was detected in the ventricle. No BNP mRNA and ANP mRNA bands were detected in other tissues including the brain.

Development of RIA for mouse BNP. A typical standard curve of mouse BNP [77-121] in the RIA using an antiserum

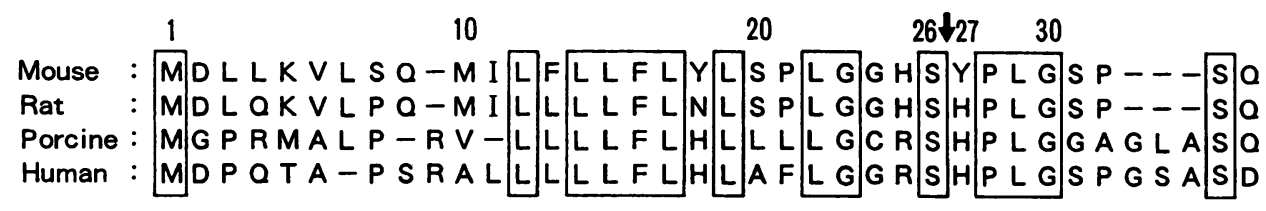

40

SPEOFKMOKLLE-- LIIREK-SEEMA-OR-OLLKD-Q-

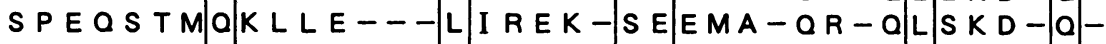

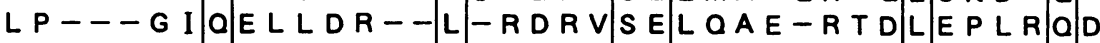

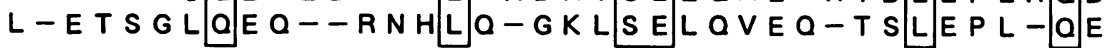

70

80

$---G L T K E H P K-R-V L R^{\top} S$ O G S T L - R-V O-O- - - - $R-P$ $---G P|T| K E L L K-R-V L R$ S O D S A - F R

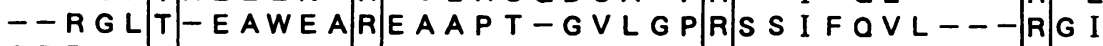
S PR - P T - G VWK SREVA-TE G I R G HRKM-- - VLYTLRA P

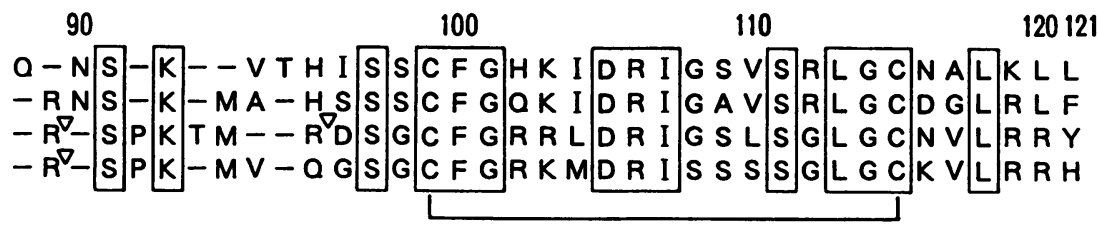

Figure 3. Alignment of mouse, rat, porcine, and human preproBNP amino acid sequences. Amino acid sequences are shown in one-letter code. Gaps (-) are introduced for maximal alignment. Identical amino acids are boxed. The proteolytic processing sites generating proBNPs are depicted by closed arrows. The processing sites for BNP are marked by closed (mouse) and open (rat, porcine, and human) arrowheads, respectively. 


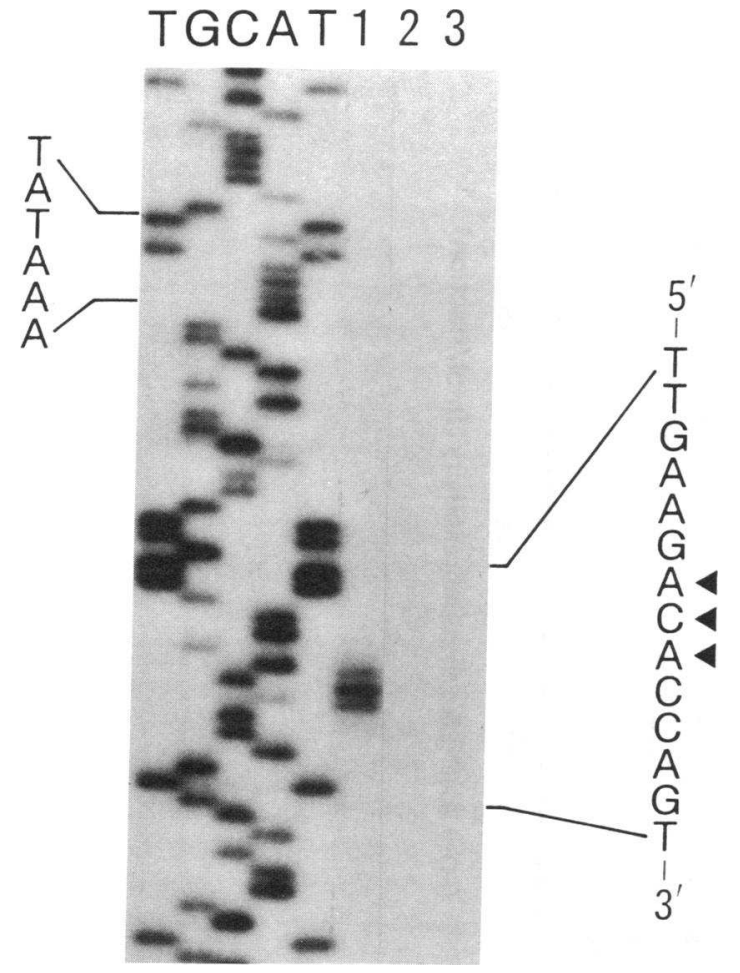

Figure 4. Primer extension analysis of the mouse BNP gene in 10wk-old BALB/c mouse. The nucleotide sequences around the TATA box are depicted. Arrowheads denote the transcription start sites. Lane 1 , ventricle; 2, liver; 3, yeast tRNA. Marker lanes $T, G, C$, and $A$ indicate sequencing ladders of the mouse BNP gene.

against mouse BNP [108-121] (M-7) is shown in Fig. $6 \mathrm{~A}$. The minimal detectable quantity in the RIA was $0.8 \mathrm{fmol} /$ tube and the $50 \%$ binding intercept was $20 \mathrm{fmol} /$ tube. The cross-reactivities of $\alpha$-ANP, porcine BNP, human BNP, and CNP were $<0.01 \%$ and that of rat BNP was $0.1 \%$. Intra- and interassay coefficients of variation were $6.5 \%(n=9)$ and $9.8 \%(n=10)$, respectively.

Tissue distributions and molecular forms of BNP in mice. Serial dilution of extracts of the mouse atrium and ventricle gave curves parallel to the standard curve of mouse BNP (Fig. 6 $B)$. Mouse BNP-LI concentrations in the atrium and ventricle of 10 -wk-old BALB/c mice were $1.12 \pm 0.12 \mathrm{nmol} / \mathrm{g}$ and

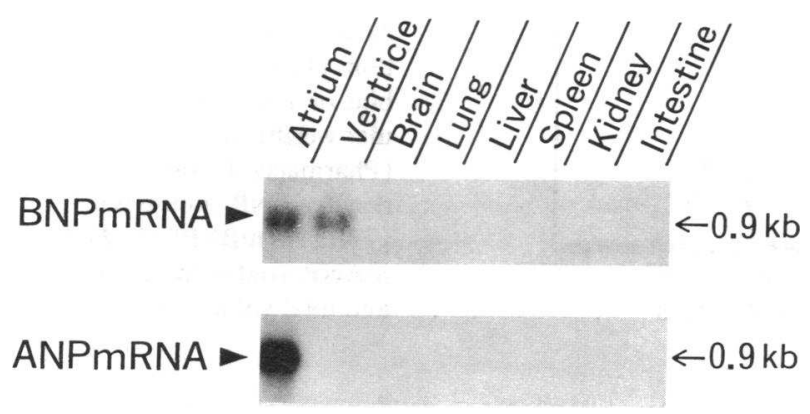

Figure 5. Northern blot analysis of mouse BNPmRNA and ANPmRNA. $3 \mu \mathrm{g}$ of total RNA from the atrium and ventricle, and $10 \mu \mathrm{g}$ of total RNA from other tissues of 10-wk-old BALB/c mice were used. The presence of intact $28 \mathrm{~S}$ and $18 \mathrm{~S}$ ribosomal RNAs was confirmed in all lanes (not shown).
(A)

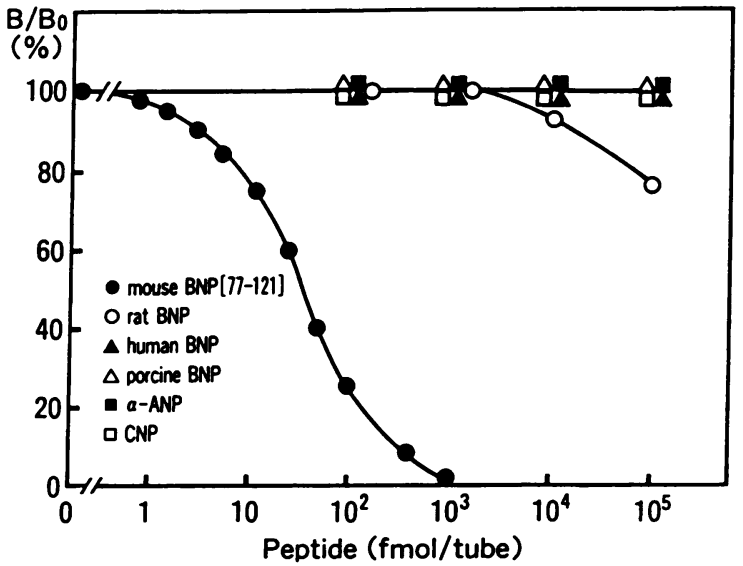

(B)

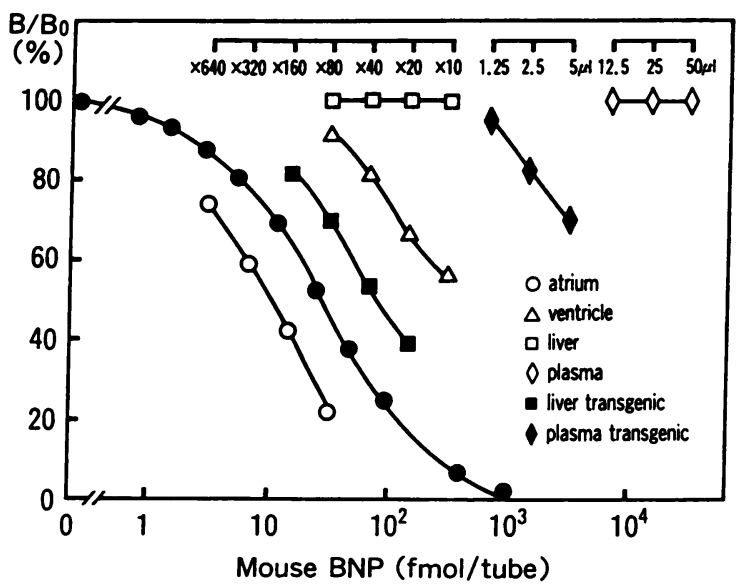

Figure 6. A typical standard curve of mouse BNP and cross-reactivity profile of its related peptides $(A)$ and dilution curves of various tissue extracts and plasma $(B)$ in the RIA for mouse BNP.

$8.3 \pm 2.0 \mathrm{pmol} / \mathrm{g}$, respectively (mean $\pm \mathrm{SEM}, n=3)$. ANP-LI concentrations in the atrium and ventricle were $12.5 \pm 1.3$ $\mathrm{nmol} / \mathrm{g}$ and $4.9 \pm 0.2 \mathrm{pmol} / \mathrm{g}$, respectively. No appreciable amounts of mouse BNP-LI $(<0.16 \mathrm{pmol} / \mathrm{g})$ and ANP-LI $(<0.052 \mathrm{pmol} / \mathrm{g}$ ) were present in the brain, lung, liver, spleen, kidney, and intestine. The tissue distributions of BNP-LI and ANP-LI were consistent with those of BNP mRNA and ANP mRNA in mice.

In Fig. 7, HP-GPC profiles of extracts from the atrium $(A)$ and ventricle $(B)$ of 10 -wk-old BALB/c mice are illustrated. Mouse BNP-LI was composed of two peaks with approximate molecular masses of 13 and $5 \mathrm{kD}$ in the atrium, and the 5-kD form was predominant (Fig. $7 \mathrm{~A}$ ). The elution position of the 5-kD mouse BNP-LI was identical to that of mouse BNP[77121]. On the other hand, the major molecular form of ANP-LI in the atrium was the precursor of $\alpha$-mouse ANP ( $\gamma$-ANP) (33). The extract from the ventricle showed essentially the same HP-GPC profile (Fig. $7 \mathrm{~B}$ ).

Generation and identification of transgenic mice. Several founder animals carrying the transgene were produced, among which four founder mice (mice 34, 51, 54, and 66) and their progeny were used for further analysis. As judged from hybridizing intensity of bands, $\sim 15$ (mouse 34 ), $\sim 50$ (mouse 51 ), $\sim 50$ (mouse 54 ), and $\sim 15$ (mouse 66 ) copies of the transgene were present in these mice (Table I). These animals 
(A)

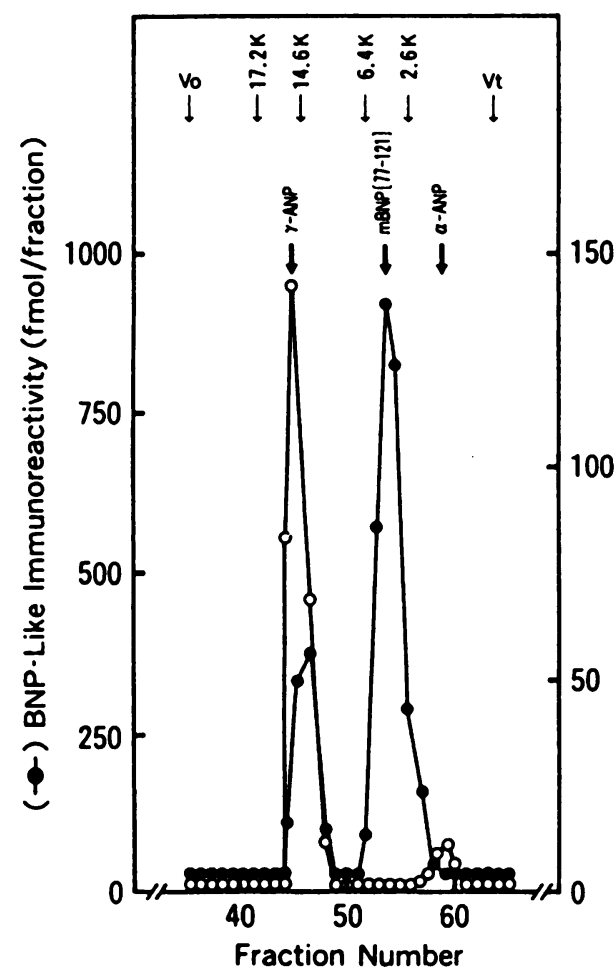

(C)

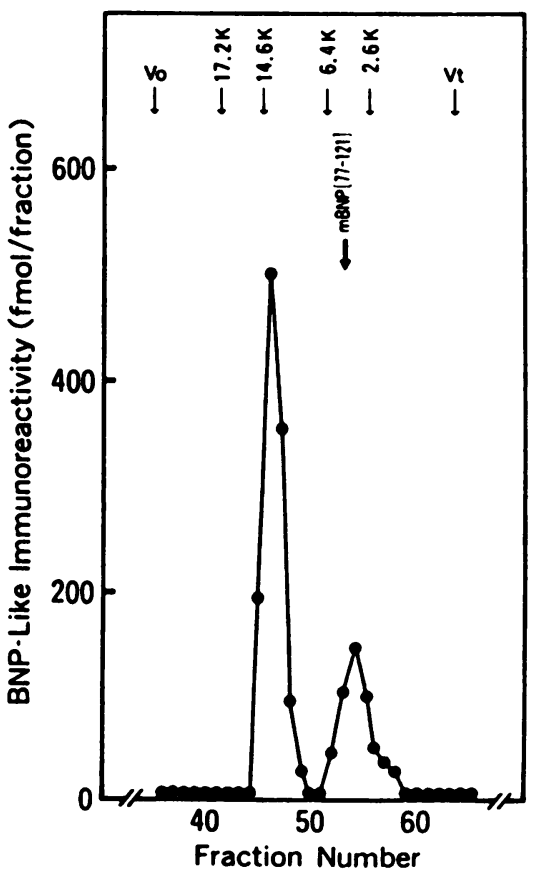

(B)

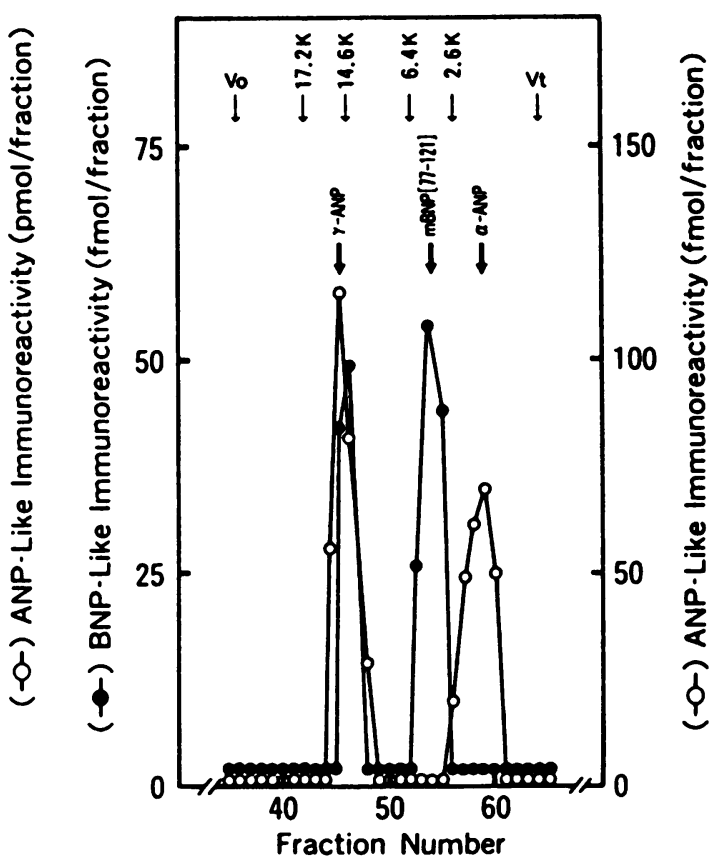

(D)

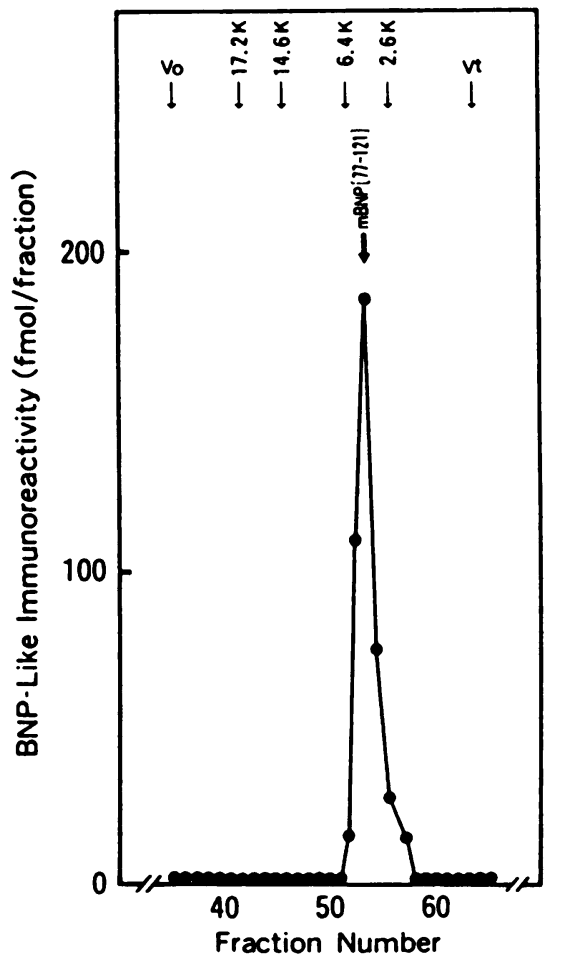

Figure 7. Typical HP-GPC profiles of extracts from the $(A)$ atrium and $(B)$ ventricle of 10 -wk old BALB/c mice, and those of extracts from the $(C)$ liver and $(D)$ plasma of the transgenic mouse 51. Arrows denote elution positions of a series of myoglobins of a polypeptide molecular weight calibration kit (Pharmacia, Uppsala, Sweden), $\gamma$-ANP, mouse BNP [77-121] (mBNP[77-121]), $\alpha$-ANP, void volume $(V o)$, and total volume $(V t)$. tended to suffer from circulatory collapse in response to heat stress.

Transgene expression in livers of transgenic mice. Northern blot analysis revealed that the transgene is expressed abundantly in the liver of BNP-transgenic mice (Fig. 8). The size of
BNP mRNA in the liver of these mice is of $0.9 \mathrm{~kb}$, the same as those in cardiac tissues (Fig. 5). An extra mRNA band of 1.1 $\mathrm{kb}$ in size was detected in livers of transgenic mice 54 and 66. The mRNA levels in the liver of BNP-transgenic mice were higher (up to 10-fold greater in transgenic mouse 66) than that 
Table I. Profile of Transgenic and Nontransgenic Littermates

\begin{tabular}{|c|c|c|c|c|}
\hline \multirow[b]{2}{*}{ Mice } & \multirow[b]{2}{*}{ Copy number } & \multirow{2}{*}{$\begin{array}{c}\text { Liver } \\
\text { BNP-LI }\end{array}$} & \multicolumn{2}{|c|}{ Plasma } \\
\hline & & & BNP-LI & CGMP \\
\hline & & $\mathrm{pmol} / \mathrm{g}$ & & \\
\hline \multicolumn{5}{|l|}{ Nontransgenic } \\
\hline $54-9$ (10 wk old $)$ & 0 & $<0.16$ & $<0.16$ & 21.4 \\
\hline $54-10$ (10 wk old $)$ & 0 & $<0.16$ & $<0.16$ & 20.3 \\
\hline $51-2$ (13 wk old) & 0 & $<0.16$ & $<0.16$ & 21.5 \\
\hline $66-6$ (24 wk old) & 0 & $<0.16$ & $<0.16$ & 23.0 \\
\hline $34-7$ (30 wk old) & 0 & $<0.16$ & $<0.16$ & 21.5 \\
\hline \multicolumn{5}{|l|}{ Transgenic } \\
\hline $54-2(10$ wk old $)$ & $\sim 50$ & 14.2 & 2.15 & 82.7 \\
\hline $54-4$ (10 wk old) & $\sim 50$ & 16.5 & 2.17 & 67.6 \\
\hline $51-1$ (13 wk old) & $\sim 50$ & 72.8 & 15.0 & 67.6 \\
\hline 66-1 (24 wk old) & $\sim 15$ & 59.9 & 8.06 & 135.7 \\
\hline 34-1 (30 wk old) & $\sim 15$ & 25.2 & 2.57 & 76.6 \\
\hline
\end{tabular}

in the ventricle of 10-wk-old BALB/c mice. The transgene expression was not detected prenatally and occurred only after the birth, and no significant expression was observed in extrahepatic tissues (not shown). The expression pattern of the transgene resembled that of the endogenous mouse SAP gene (20).

To map the transcription start site of the transgene, primer

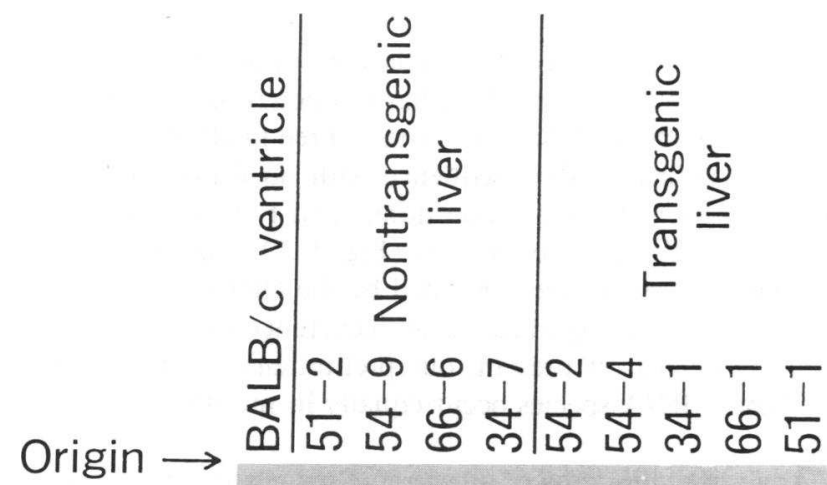

Figure 8. Northern blot analysis of BNPmRNA in livers of BNPtransgenic mice and their nontransgenic littermates. $5 \mu \mathrm{g}$ of total RNA from livers of mice were used.

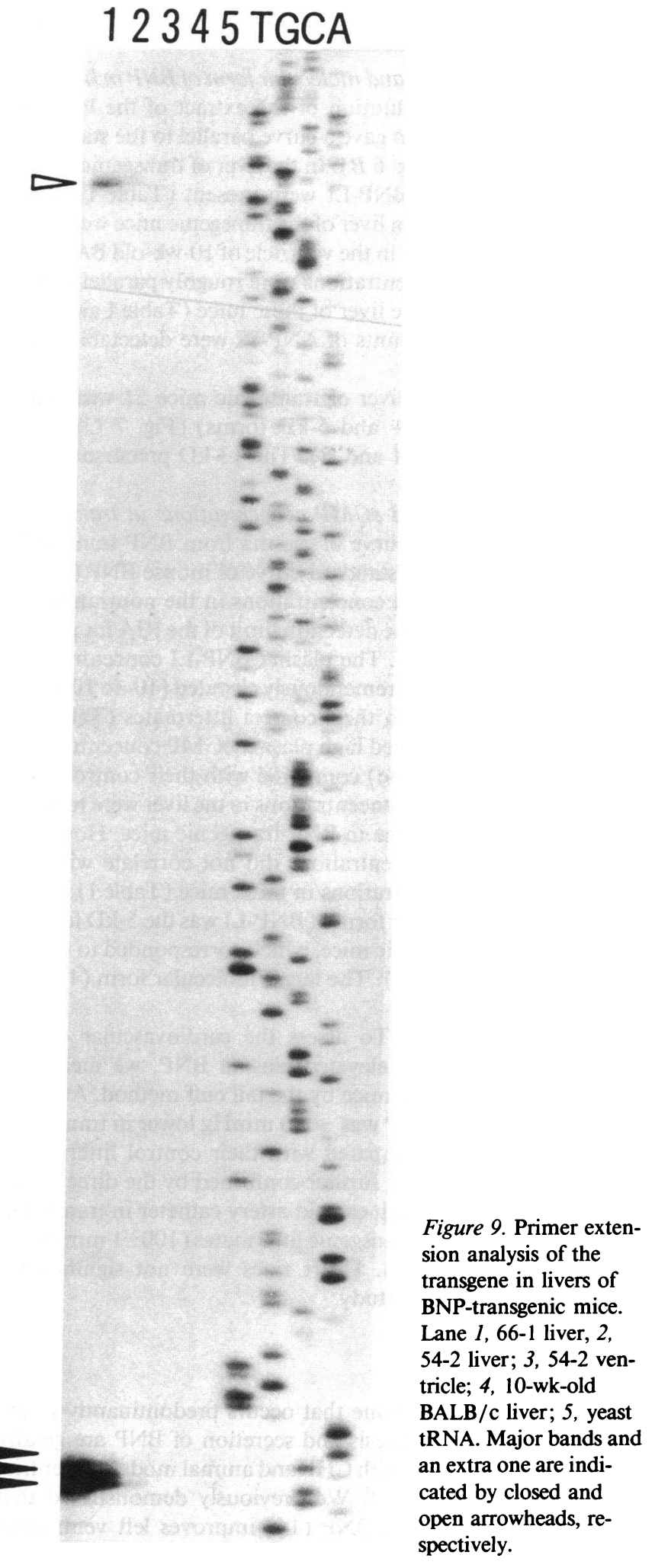

extension analysis was performed (Fig. 9). When RNA from the livers of transgenic mice 66-1 and 54-2 was used, strongly positive bands were observed, corresponding to those using RNA from the ventricle. An extra positive one was present $\sim 160$ bp upstream to the major start site. These results suggest that the extra 1.1-kb mRNA band represents aberrant tran- 
scripts directed probably from the TATA box in the human SAP promoter (Fig. 2).

Tissue concentration and molecular form of BNP in livers of transgenic mice. Serial dilution of the extract of the liver of BNP-transgenic mice also gave a curve parallel to the standard curve of mouse BNP (Fig. $6 \mathrm{~B}$ ). In the liver of transgenic mice, significant amounts of BNP-LI were present (Table I). The BNP-LI concentrations in liver of the transgenic mice were two to nine times higher than in the ventricle of 10 -wk-old $B A L B / c$ mice. The BNP-LI concentrations were roughly parallel to the BNP mRNA levels in the liver of these mice (Table I and Fig. 8). No appreciable amounts of ANP-LI were detectable (not shown).

The BNP-LI in the liver of transgenic mice 51 was composed of two peaks (13- and 5-kD forms) (Fig. $7 C$ ) as in cardiac tissues (Fig. 7, $A$ and $B$ ). The $13-\mathrm{kD}$ precursor form was predominant.

Plasma BNP-LI and cGMP concentrations in transgenic mice. A serial dilution curve of plasma from BNP-transgenic mice was parallel to the standard curve of mouse BNP (Fig. 6 $B)$. The plasma BNP-LI concentrations in the nontransgenic littermates were below the detection limit of the RIA for mouse BNP $(<0.16 \mathrm{pmol} / \mathrm{ml})$. The plasma BNP-LI concentrations in transgenic mice were tremendously elevated (10- to 100 -fold increase) compared with their control littermates (Table I). These animals also showed high plasma cGMP concentrations (three- to sixfold increase) compared with their control mice (Table I). The BNP-LI concentrations in the liver were roughly parallel to those in plasma in BNP-transgenic mice. However, the plasma cGMP concentrations did not correlate with the plasma BNP-LI concentrations in these mice (Table I).

The major molecular form of BNP-LI was the 5-kD form in plasma of BNP-transgenic mice, which corresponded to mouse BNP [77-121] (Fig. $7 \mathrm{D}$ ). The larger molecular form (13 kD) was not detected.

$B P$ measurements. To assess the cardiovascular consequences of chronically elevated plasma BNP, we measured SBP in BNP-transgenic mice by the tail cuff method. As summarized in Table II, SBP was $\sim 20 \mathrm{mmHg}$ lower in transgenic mice 54 and 34 as compared with their control littermates. These observations were further confirmed by the direct measurement of SBP through carotid artery catheter in transgenic mice 34 and their nontransgenic littermates $(100 \pm 1 \mathrm{mmHg}$ vs. $125 \pm 2 \mathrm{mmHg}, n=3$ ). Heart rates were not significantly changed in the present study.

\section{Discussion}

BNP is a cardiac hormone that occurs predominantly in the ventricle (9-11). Synthesis and secretion of BNP are greatly augmented in patients with $\mathrm{CHF}$ and animal models of ventricular hypertrophy (9-12). We previously demonstrated that acute administration of BNP (14) improves left ventricular function by its potent natriuretic and vasorelaxant activity. However, previous studies gave no definite evidence for the roles of BNP in chronic cardiovascular regulation. To address this issue, the present study was designed to generate transgenic mice with elevated plasma BNP concentration. Given the marked structural divergence of BNP among species, we first isolated the mouse BNP cDNA and genomic clones. Using the mouse BNP coding sequences, we generated transgenic mice with chronically elevated plasma BNP concentration.
Table II. Comparison of BP of Transgenic and Nontransgenic Mice Measured by the Tail Cuff Method

\begin{tabular}{lccc}
\hline \multicolumn{1}{c}{ Mice } & No. of mice & SBP & Heart rate \\
\hline & & $m m H g$ & beats/min \\
Nontransgenic 54 (10 wk old) & 6 (m 4, f 2) & $126 \pm 2$ & $470 \pm 31$ \\
Transgenic 54 (10 wk old) & 4 (m 2, f 2) & $106 \pm 1^{*}$ & $482 \pm 45$ \\
Nontransgenic 34 (30 wk old) & 3 (m 1, f 2) & $120 \pm 1$ & $400 \pm 16$ \\
Transgenic 34 (30 wk old) & 3 (m 1, f 2) & $98 \pm 3^{*}$ & $481 \pm 40$ \\
& & & \\
\hline
\end{tabular}

$\mathrm{m}$, male; f, female.

${ }^{*} P<0.01$ : statistically significant compared with each control group, respectively (Tukey's $t$ test).

The present study demonstrates that the mouse BNP gene is composed of three exons and two introns. The exon/intron organization of the mouse BNP gene is similar to those of the ANP and BNP genes from other species (31-34): In the 5'flanking region, there are two GATA elements. The GATA element has been demonstrated to be implicated in cell typespecific transcription of several genes (27). The 5'-flanking regions of the dog, porcine, and human BNP genes also contain two GATA sequences (31). These sequences may play some roles in the BNP gene transcription. The 3 '-untranslated region of the mouse BNP gene contains the AT-rich sequences implicated in mRNA instability (28), which are also found in the BNP genes from other species (29-32). These sequences are not found in the ANP genes $(33,34)$, suggesting differential regulation of the BNP and ANP gene expressions at the mRNA level.

In the present study, two different mouse BNP cDNA clones were identified: one clone has an open reading frame for 121 amino acids, and the other with a three-nucleotide (AAG for $\mathrm{Lys}^{43}$ ) shorter coding sequence with no frame shift. On close inspection, there are one donor and two acceptor sites (26) around the junction region (Fig. $1 B$ ), suggesting that these mRNA species are generated by the alternative mRNA splicing. Although significance of occurrence of two mRNA species is unclear at present, our preliminary results suggest that these mRNA species occur equally in mouse cardiac tissues.

Analysis of the deduced amino acid sequences revealed that mouse preproBNP comprises 121 (or 120) amino acids. The proteolytic processing site $\left(\mathrm{Arg}^{73}-\mathrm{Val}^{74}-\mathrm{Leu}^{75}-\mathrm{Arg}^{76}\right.$ ) generating BNP is identical between mouse and rat precursors (29, $32)$. This sequence is also highly conserved in the processing site of porcine, and human preproBNPs (Fig. 3) (30, 31), and is consistent with the recognition site ( $\mathrm{Arg}-\mathrm{X}$-X-Arg) for yeast Kex 2-like processing endopeptidases (35). Furthermore, HPGPC coupled with an RIA for mouse BNP showed that the elution position of the 5-kD form of mouse BNP-LI in cardiac tissues is identical to that of mouse BNP[77-121]. Taken together, these results suggest that the COOH-terminal 45-residue peptide of mouse preproBNP (mouse BNP [77-121]) represents mouse BNP. In this regard, the 120-residue preproBNP does not affect the structure of mouse BNP. Mouse BNP is only $64 \%$ homologous to rat BNP, further showing the structural divergence of BNP among species.

The mouse BNP gene was expressed abundantly in the ventricle as well as in the atrium, while the ANP gene was expressed only in the atrium. Taking account of tissue weight, 
ventricular expression of the BNP gene predominates its atrial expression. Thus, in mice, the ventricle is also a major site of BNP production, whereas ANP is produced by the atrium. Although BNP was first isolated from the porcine brain (7), no significant amounts of BNP mRNA and peptide were present in other tissues including the brain in mice. In contrast, the distribution patterns of BNP mRNA and peptide in mice are similar to those in rats $(9,29)$, suggesting the species difference in the tissue distribution of BNP. Furthermore, HP-GPC studies suggested that the major storage form of BNP is the cleaved mature peptide in cardiac tissues. The processing pattern of mouse BNP is similar to those of rat and human $\operatorname{BNPs}(9,10)$, but differs from that of porcine BNP (8), suggesting the marked species-specific difference of the processing pattern as well as the structure, tissue distribution, and biological actions of BNP.

Given the structural divergence of BNP among species as described above, we generated transgenic mice with elevated plasma BNP concentration by introducing the homologous mouse BNP coding sequences. The liver is suitable to overproduce the hormone because of its high biosynthetic capacity. Therefore, the human SAP/mouse BNP fusion gene was constructed so as to target the hormone expression to the liver. In the liver of BNP-transgenic mice, significant levels of mouse BNP mRNA and peptide were detected, reaching up to 10-fold greater than in the ventricle. Taking account of tissue weight, the liver of these mice produces at least 100 -fold larger amount of BNP than the ventricle. The BNP-LI in the transgenic mouse liver is also composed of 13- and 5-kD peaks, and the $13-\mathrm{kD}$ form is predominant, while the major circulating form is the $5-\mathrm{kD}$ form. Therefore, the proteolytic cleavage of mouse BNP precursor occurs just before or during its secretion from the liver. These results also indicate that the liver is capable of secreting the cleaved mature BNP peptide into the circulation.

In BNP-transgenic mice, the plasma BNP concentration is tremendously elevated $(2.1-15.0 \mathrm{pmol} / \mathrm{ml})$, which exceeds those in patients with $\mathrm{CHF}(\sim 500 \mathrm{fmol} / \mathrm{ml})(10)$. Natriuretic peptides exert most of their biological actions by activating guanylyl cyclase (GC)-coupled receptors, thereby leading to increase in the cGMP production $(1,2)$. In the present study, the plasma cGMP concentration is elevated by two- to sixfold in response to augmented secretion of BNP, suggesting that GC-coupled receptors are activated in BNP-transgenic mice. Therefore, these animals provide a useful model system with which to assess the roles of augmented secretion of BNP in chronic cardiovascular regulation.

These BNP-transgenic mice had low BP that is $\sim 20$ $\mathrm{mmHg}$ lower than their nontransgenic littermates. Because the plasma cGMP concentration, a biochemical marker for vasodilating activity of natriuretic peptides $(24,36)$, is elevated in these mice, reduction in BP is mediated by GC-coupled receptors. These mice tended to suffer from circulatory collapse in response to heat stress, suggesting the volume-depleted state in these animals. Preliminary results indicate that there are no significant differences in urine volume and water intake between transgenic and nontransgenic littermates. The urine volume could be increased in response to augmented secretion of BNP after the birth, thereby contributing to the volume-depleted state. These possible changes in body fluid homeostasis might also contribute to the observed reduction in BP. It has been reported that ANP-transgenic mice with elevated plasma ANP concentration $(\sim 1.7 \mathrm{pmol} / \mathrm{ml})$ showed $25-30 \mathrm{mmHg}$ reduction in BP (37). Similarly, these mice did not differ from their nontransgenic littermates in water intake, urine volume, and sodium excretion. Thus, the authors postulated that reduction in BP is attributed to direct action of ANP on the vasculature.

Natriuretic peptide receptors include two subtypes of GCcoupled receptors (guanylyl cyclase-A [GC-A] and guanylyl cyclase-B [GC-B]) and a clearance receptor (C receptor) (10, $38-40)$. We and others previously demonstrated that the rank order of ligand selectivity for GC-A and GC-B is ANP $\geq$ BNP $>>$ CNP and CNP $>$ ANP $\geq$ BNP, respectively $(38,39)$. Recently, a variant form of GC-B has been cloned, which may be generated by the alternative mRNA splicing mechanism (41). Furthermore, a new subtype of GC-coupled receptor with the highest affinity to BNP is suggested to be present $(17,40)$. We also showed that the rank order of ligand selectivity for $C$ receptor is ANP > CNP > BNP, and that BNP is cleared more slowly than ANP from the circulation (10). The slower clearance of BNP from the circulation may modify the biological actions of BNP through GC-coupled receptors. In addition, tissue distribution of these receptors has not fully been described. Therefore, the mechanisms for the biological actions of natriuretic peptides should be very complex in vivo. Although ANP-transgenic mice with elevated plasma ANP concentration showed lower BP as compared with their controls (37), it is unclear whether BNP can cause the hypotensive response in BNP-transgenic mice. In addition, even so, the mechanisms should be different between BNP- and ANPtransgenic mice. In the present study, we demonstrated that BNP actually cause the chronic hypotensive response in BNPtransgenic mice. A yet unidentified receptor with the highest affinity to BNP might also contribute to reduction in BP in BNP-transgenic mice. Further studies are necessary to clarify the mechanisms by which augmented secretions of BNP and ANP decrease BP in these animal models. In this regard, the BNP-transgenic mice generated in the present study will give us a clue to elucidate the functional differences between BNP and ANP and to identify a BNP-specific receptor.

The plasma BNP concentration was roughly parallel to the BNP concentration in the liver of BNP-transgenic mice, however, the plasma cGMP concentration did not correlate with the plasma BNP concentration. This may be explained by possible differences in the down-regulation of GC-coupled receptors in response to high concentration of BNP as well as in the processing pattern of BNP in the liver among transgenic mouse lineages. It is highly likely that the biological potency is different between BNP and its precursor as in the case with ANP. Differences in $\mathrm{BNP} /$ its precursor ratio may give rise to those in the plasma cGMP concentration in these mice.

It has been suggested that GC-coupled receptors are possibly down-regulated in response to high concentrations of natriuretic peptides in patients with severe CHF (42). We previously demonstrated that acute BNP infusion (14) improves left ventricular function by its prominent natriuretic and vasodilatory activity, and suggested the usefulness of BNP as a shortterm therapeutic agent for cardiovascular disorders. The usefulness of BNP as a long-term therapeutic agent, however, has been controversial because potential down-regulation of GCcoupled receptors may lead to blunted responses to BNP. In the present study, however, the plasma cGMP concentration was elevated even 30 wk after the birth in BNP-transgenic mice, which is compatible to those attained by acute BNP infusion 
(the peak plasma cGMP concentration of $\sim 90 \mathrm{pmol} / \mathrm{ml}$ ) (14). Furthermore, significant reduction in BP was observed in these mice. These observations indicate that the GC-coupled natriuretic peptide receptors are not saturated even if down-regulated, and provide the direct evidence that BNP is involved in the long-term cardiovascular regulation. Although there may be differences in various physiologic parameters (sympathetic activity etc.) between the mouse models and humans, these results also suggest the potential usefulness of BNP as a long-term as well as a short-term therapeutic agent.

In conclusion, we isolated mouse BNP cDNA and genomic clones, and generated transgenic mice with elevated plasma BNP concentration. The present study demonstrates that these transgenic mice provide a useful model system with which to assess the roles of BNP in chronic cardiovascular regulation and suggests the potential usefulness of BNP as a long-term therapeutic agent.

Note: During the preparation of the manuscript, M. E. Steinhelper reported the isolation of the mouse BNP gene (43). The nucleotide sequences reported differ slightly from those in this study, resulting in four amino acid substitutions in mouse preproBNP $\left(\mathrm{Tyr}^{27} \rightarrow \mathrm{His}^{27}, \mathrm{Gly}^{30} \rightarrow \mathrm{Glu}^{30}, \mathrm{Lys}^{40} \rightarrow \mathrm{Leu}^{40}\right.$, Pro $^{71} \rightarrow$ Leu $\left.^{71}\right)$.

\section{Acknowledgments}

We thank Dr. J. Miyazaki, who generously gave the pSG 2 vector, and Mr. H. Iwanaga for his technical assistance in peptide synthesis. We also acknowledge Ms. H. Kitoh, Ms. M. Shida, and Ms. K. Sasamoto for their secretarial and technical assistance.

This work was supported in part by research grants from the Japanese Ministry of Education, Science and Culture, the Japanese Ministry of Health and Welfare "Disorders of Adrenal Hormone" Research Committee, Japan, 1992, Smoking Research Foundation, Yamanouchi Foundation for Research on Metabolic Disorders, Salt Science Research Foundation, Senri Life Science Foundation and by research grant for cardiovascular diseases (2A-3) from the Japanese Ministry of Health and Welfare.

\section{References}

1. Rosenzweig, A., and C. E. Seidman. 1991. Atrial natriuretic factor and related peptide hormones. Annu. Rev. Biochem. 60:229-255.

2. Nakao, K., Y. Ogawa, S. Suga, and H. Imura. 1992. Molecular biology and biochemistry of the natriuretic peptide system. I. Natriuretic peptides. J. Hypertens. 10:907-912.

3. Sugawara, A., K. Nakao, N. Morii, T. Yamada, H. Itoh, S. Shiono, Y. Saito, M. Mukoyama, H. Arai, K. Nishimura, et al. 1988. Synthesis of atrial natriuretic polypeptide (ANP) in human failing hearts: evidence for altered processing of ANP and augmented synthesis of $\beta$-human ANP. J. Clin. Invest. 81:1962-1970.

4. Arai, H., K. Nakao, Y. Saito, N. Morii, A. Sugawara, T. Yamada, H. Itoh S. Shiono, M. Mukoyama, H. Ohkubo, et al. 1988. Augmented expression of atrial natriuretic polypeptide (ANP) gene in ventricles of spontaneously hypertensive rats (SHR) and SHR-stroke prone. Circ. Res. 62:926-930.

5. Edwards, B. S., D. M. Achermann, M. E. Lee, G. S. Reeder, L. E. Wold, and J. C. Burnett Jr. 1988. Identification of atrial natriuretic factor within ventricular tissue in hamsters and humans with congestive heart failure. J. Clin. Invest. 81:82-86

6. Saito, Y., K. Nakao, H. Arai, K. Nishimura, K. Okumura, K. Obata, G. Takemura, H. Fujiwara, A. Sugawara, T. Yamada, et al. 1989. Augmented expression of atrial natriuretic polypeptide gene in ventricle of human failing heart. J. Clin. Invest. 83:298-305.

7. Sudoh, T., K. Kangawa, N. Minamino, and H. Matsuo. 1988. A new natriuretic peptide in porcine brain. Nature (Lond.). 332:78-819.

8. Saito, Y., K. Nakao, H. Itoh, T. Yamada, M. Mukoyama, H. Arai, K Hosoda, G. Shirakami, S. Suga, N. Minamino, et al. 1989. Brain natriuretic peptide is a novel cardiac hormone. Biochem. Biophys. Res. Commun. 158:360368.

9. Ogawa, Y., K. Nakao, M. Mukoyama, G. Shirakami, H. Itoh, K. Hosoda,
Y. Saito, H. Arai, S. Suga, M. Jougasaki, et al. 1990. Rat brain natriuretic peptide: tissue distribution and molecular form. Endocrinology. 126:2225-2227.

10. Mukoyama, M., K. Nakao, K. Hosoda, S. Suga, Y. Saito, Y. Ogawa, G. Shirakami, M. Jougasaki, K. Obata, H. Yasue, et al. 1991. Brain natriuretic peptide as a novel cardiac hormone in humans: evidence for an exquisite dual natriuretic peptide system, atrial natriuretic peptide and brain natriuretic peptide. J. Clin. Invest. 87:1402-1412.

11. Ogawa, Y., K. Nakao, M. Mukoyama, K. Hosoda, G. Shirakami, H. Arai, Y. Saito, S. Suga, M. Jougasaki, and H. Imura. 1991. Natriuretic peptides as cardiac hormones in normotensive and spontaneously hypertensive rats: the ventricle is a major site of synthesis and secretion of brain natriuretic peptide. Circ. Res. 69:491-500.

12. Takahashi, T., P. D. Allen, and S. Izumo. 1992. Expression of A-, B- and C-type natriuretic peptide genes in failing and developing human ventricles: correlation with expression of the $\mathrm{Ca}^{2+}$-ATPase gene. Circ. Res. 71:9-17.

13. Morita, E., H. Yasue, M. Yoshimura, H. Ogawa, M. Jougasaki, T. Matsumura, M. Mukoyama, and K. Nakao. 1993. Increased plasma levels of brain natriuretic peptide in patients with acute myocardial infarction. Circulation. 88:82-91.

14. Yoshimura, M., H. Yasue, E. Morita, N. Sakaino, M. Jougasaki, M. Kurose, M. Mukoyama, Y. Saito, K. Nakao, and H. Imura. 1991. Hemodynamic, renal, and hormonal responses to brain natriuretic peptide infusion in patients with congestive heart failure. Circulation. 84:1581-1588.

15. Saito, Y., K. Nakao, K. Nishimura, A. Sugawara, K. Okumura, K. Obata, R. Sonoda, T. Ban, H. Yasue, and H. Imura. 1987. Clinical application of atrial natriuretic polypeptide to patients with congestive heart failure: beneficial effects on left ventricular function. Circulation. 76:115-124.

16. Field, L. J. 1993. Transgenic mice in cardiovascular research. Annu. Rev. Physiol. 55:97-114.

17. Kambayashi, Y., K. Nakao, H. Kimura, T. Kawabata, M. Nakamura, K. Inouye, N. Yoshida, and H. Imura. 1990. Biological characterization of human BNP and rat BNP: species-specific actions of BNP. Biochem. Biophys. Res. Commun. 173:599-605.

18. Ogawa, Y., K. Nakao, O. Nakagawa, Y. Komatsu, K. Hosoda, S. Suga, H Arai, K. Nagata, N. Yoshida, and H. Imura. 1992. Human C-type natriuretic peptide: characterization of the gene and peptide. Hypertension. 19:809-813.

19. Hosoda, K., K. Nakao, N. Tamura, H. Arai, Y. Ogawa, S. Suga, S. Nakanishi, and H. Imura. 1992. Organization, structure, chromosomal assignment, and expression of the gene encoding the human endothelin-A receptor. J. Biol. Chem. 267:18797-18804.

20. Zhao, X., K. Araki, J. Miyazaki, and K. Yamamura. 1992. Developmental and liver-specific expression directed by the serum amyloid $\mathrm{P}$ component promoter in transgenic mice. J. Biochem. 111:736-738.

21. Suematsu, S., T. Matsusaka, T. Matsuda, S. Ohno, J. Miyazaki, K. Yamamura, T. Hirano, and T. Kishimoto. 1992. Generation of plasmacytomas with the chromosomal translocation $\mathrm{t}(12 ; 15)$ in interleukin 6 transgenic mice. Proc. Natl. Acad. Sci. USA. 89:232-235.

22. Hogan, B., F. Costantini, and L. Lacy. 1986. Manipulating the Mouse Embryo: A Laboratory Manual. Cold Spring Harbor Laboratory, Cold Spring Harbor, NY. 332 pp.

23. Sanger, F., S. Nicklen, and A. R. Coulson. 1977. DNA sequencing with chain-terminating inhibitors. Proc. Natl. Acad. Sci. USA. 74:5463-5469.

24. Itoh, H., K. Nakao, M. Mukoyama, T. Yamada, K. Hosoda, G. Shirakami, N. Morii, A. Sugawara, Y. Saito, S. Shiono, et al. 1989. Chronic blockade of endogenous atrial natriuretic polypeptide (ANP) by monoclonal antibody against ANP accelerates the development of hypertension in spontaneously hypertensive and DOCA-salt hypertensive rats. J. Clin. Invest. 84:145-154.

25. Matsuda, S., K. Kurokawa, K. Higuchi, N. Imamura, H. Hakata, and M. Ueda. 1987. A new blood pressure measuring apparatus equipped with a microcomputer system for conscious rats. J. Pharmacol. Methods. 17:361-376.

26. Breathnach, R., and P. Chambon. 1981. Organization and expression of eucaryotic split genes coding for proteins. Annu. Rev. Biochem. 50:349-383.

27. Wilson, D. B., D. M. Dorfman, and S. H. Orkin. 1990. A nonerythroid GATA-binding protein is required for function of the human preproendothelin-1 promoter in endothelial cells. Mol. Cell. Biol. 10:4854-4862.

28. Shaw, G., and R. Kamen. 1986. A conserved AU sequence from the 3 untranslated region of GM-CSF mRNA mediates selective mRNA degradation. Cell. 46:659-667.

29. Kojima, K., N. Minamino, K. Kangawa, and H. Matsuo. 1989. Cloning and sequence analysis of cDNA encoding a precursor for rat brain natriuretic peptide. Biochem. Biophys. Res. Commun. 159:1420-1426.

30. Sudoh, T., K. Maekawa, M. Kojima, N. Minamino, K. Kangawa, and H. Matsuo. 1989. Cloning and sequence analysis of cDNA encoding a precursor for human brain natriuretic peptide. Biochem. Biophys. Res. Commun. 159:14271434.

31. Seilhamer, J. J., A. Arfsten, J. A. Miller, P. Lundquist, R. M. Scarborough, J. A. Lewicki, and J. G. Porter. 1989. Human and canine gene homologs of porcine brain natriuretic peptide. Biochem. Biophys. Res. Commun. 165:650658. 
32. Roy, R. N., and T. G. Flynn. 1990. Organization of the gene for iso rANP, a rat B-type natriuretic peptide. Biochem. Biophys. Res. Commun. 171:416-423.

33. Seidman, C. E., K. D. Bloch, K. A. Klein, J. A. Smith, and J. G. Seidman. 1984. Nucleotide sequences of the human and mouse atrial natriuretic factor genes. Science (Wash. DC). 226:1206-1209.

34. Argentin, S., M. Nemer, J. Drouin, G. K. Scott, B. R. Kennedy, and P. L. Davies. 1985. The gene for rat atrial natriuretic factor. J. Biol. Chem. 260:45684571.

35. Molloy, S. S., P. A. Bresnahan, S. H. Leppla, K. R. Klimpel, and G. Thomas. 1992. Human furin is a calcium-dependent serine endoprotease that recognizes the sequence Arg-X-X-Arg and efficiently cleaves anthrax toxin protective antigen. J. Biol. Chem. 267:16396-16402.

36. Hamet, P., J. Tremblay, S. C. Pang, R. Skuherska, E. L. Schiffrin, R Garcia, M. Cantin, J. Genest, R. Palmour, F. R. Erwin, et al. 1986. Cyclic GMP as mediator and biological marker of atrial natriuretic factor. J. Hypertens. 4(Suppl. 2):S49-S56.

37. Steinhelper, M. E., K. L. Cochrane, and L. J. Field. 1990. Hypotension in transgenic mice expressing atrial natriuretic factor fusion genes. Hypertension. 16:301-307.
38. Suga, S., K. Nakao, K. Hosoda, M. Mukoyama, Y. Ogawa, G. Shirakami, H. Arai, Y. Saito, Y. Kambayashi, K. Inouye, et al. 1992. Receptor selectivity of natriuretic peptide family, atrial natriuretic peptide, brain natriuretic peptide, and C-type natriuretic peptide. Endocrinology. 130:229-239.

39. Koller, K. J., D. G. Lowe, G. L. Bennett, N. Minamino, K. Kangawa, H. Matsuo, and D. V. Goeddel. 1991. Selective activation of the B natriuretic peptide receptor by C-type natriuretic peptide (CNP). Science (Wash. DC). 252:120-123.

40. Garbers, D. L. 1992. Guanylyl cyclase receptors and their endocrine, paracrine, and autocrine ligands. Cell. 71:1-4.

41. Ohyama, Y., K. Miyamoto, Y. Saito, N. Minamino, K. Kangawa, and H. Matsuo. 1992. Cloning and characterization of two forms of C-type natriuretic peptide receptor in rat brain. Biochem. Biophys. Res. Commun. 183:743-749.

42. Tsutamoto, T., T. Kanamori, N. Morigami, Y. Sugimoto, O. Yamaoka, and M. Kinoshita. 1993. Possibility of downregulation of atrial natriuretic peptide receptor coupled to guanylate cyclase in peripheral vascular beds of patients with chronic severe heart failure. Circulation. 87:70-75.

43. Steinhelper, M. E. 1993. Structure, expression, and genomic mapping of the mouse natriuretic peptide type-B gene. Circ. Res. 72:984-992. 